\title{
Engaging the United States Network of Biosphere Reserves in a changing social- political context
}

\author{
Jennifer M. Thomsen, Kelly L. Cerialo, Sarah M. Gaines \& Jeremy S. Dertien
}

Keywords: biosphere reserve, Champlain-Adirondack, diversity, governance

\section{Abstract}

The United States was an integral part of the early growth of UNESCO's Man and the Biosphere Programme (MAB), yet changing political and social contexts have impacted the relationship between the US and MAB. Poised at the start of a new period of activity, as the US reviews its strategy on its current and future engagement with MAB, it is critical to discuss the factors that have influenced the history of US involvement in the World Network of Biosphere Reserves (WNBR) and how the US will engage in the future. For the purpose of this article, the US Biosphere Network (USBN) refers to the current recently reinvigorated network of biosphere reserves in the US. As many of the USBN sites are partially or fully mountainous ecosystems, the renewed engagement of the USBN will contribute to the conservation of some of the nation's most prized mountain landscapes. This article provides an overview of the biosphere reserve concept and of US involvement with the intergovernmental programme. We discuss challenges facing the USBN, including relevancy and inclusion, political relations with UNESCO, and perceptions of zoning. We present examples of opportunities and strategies that have been implemented by the Champlain-Adirondack Biosphere Network in a mountain region, followed by conclusions on revisioning MAB in the US and globally for the next 50 years.

\section{Introduction}

In 1971, UNESCO established the Man and the Biosphere Programme (MAB) to integrate social and ecological dimensions of the landscape beyond traditional protected area boundaries (Ishwaran et al. 2008), the Biosphere Reserves (BRs) being one of a series of six programmes of implementation. In 2021, UNESCO's MAB is celebrating its $50^{\text {th }}$ anniversary as an "intergovernmental scientific programme that aims to establish a scientific basis for enhancing the relationship between people and their environments" (UNESCO 2020). The hallmark of MAB, the World Network of Biosphere Reserves (WNBR), now numbering 727 sites in 131 countries, including 22 transboundary sites, is well established in its efforts for "improving human livelihoods and safeguarding natural and managed ecosystems, thus promoting innovative approaches to economic development that are socially and culturally appropriate and environmentally sustainable" (UNESCO 2020).

The United States (US) was an integral part of the early growth of MAB, yet, as political and social contexts changed over time, so did the relationship between the US and MAB (Gilbert 2014). Mistrust of the United Nations and a politically polarized mistrust of science and environmental management by a substantial proportion of the US public, such as the one-third of the nation that denies human-caused climate change (Leiserowitz et al. 2019; Shear \& Davenport 2020), have potentially contributed to low public awareness of MAB and the US Biosphere Network (USBN). For the purpose of this article, the USBN refers to the current network of BRs in the US. The omissions of the words Man and Reserve were intentional decisions by the US Biosphere Working Group and reflect the sentiments discussed in this article. As the US reviews its strategy on its current and future engagement with $\mathrm{MAB}$, it is critical to discuss the factors that have influenced the history of US involvement in the WNBR and how the US will engage in the future. As the majority of the sites in the USBN are partially or fully mountainous ecosystems, renewed engagement of the USBN will be especially important in the conservation of some of the nation's most prized mountain landscapes.

This article aims to address these issues by providing an overview of the BR concept and a brief history of the US involvement with the intergovernmental programme. We then discuss several challenges facing the USBN, including relevancy and inclusion, political turnover and relations with UNESCO, and perceptions of zoning. We present various opportunities and strategies that have been implemented by the Champlain-Adirondack Biosphere Network (CABN), and conclusions on revisioning the USBN and WNBR for the next 50 years.

\section{History of US MAB Programme}

Most US BRs received their designation between 1976 and 1980, with a historic high of 47 US BRs at the time of the most recent (2017) periodic review. The initial model for BRs was to preserve examples of unique ecosystems around the world, as reflected in the numerous experimental forests and biological research stations designated in the US as BRs in the early years of the programme. Prompted by a collaborative agreement between the US and Russia to jointly designate and research BRs (Franklin 1977), the WNBR expanded rapidly in the 1970s and 1980s in numerous countries. Later, the model evolved to include the current zonation system, which explicitly includes space for development activities, highlighting how MAB was 
an early leader in sustainable development. Soon after the establishment of the UNESCO MAB programme, the US Department of State created a National Committee in 1974, with members coming primarily from federal and state agencies (Thomsen 2018). However, the US has had a tumultuous relationship with UNESCO: in 1974, US President Gerald Ford froze payments to UNESCO after it recognized the Palestinian Liberation Organization (Waxman 2017); and the US left UNESCO in 1983 under President Ronald Reagan.

In the mid-1990s, distrust of the United Nations within the US, along with the importance of private property and westward expansion underlying US national identity, led to the proposal of the American Sovereignty Protection Act to Congress in 1996-1997 (Shafer 2004). As Congress support waned, oversight of MAB in the US transitioned to the US Forest Service in 2000, although the agency was limited in its resources to support the programme (Thomsen 2018). The US MAB Programme was reinvigorated in 2002 with the establishment of the Biosphere Reserve Association and with the re-engagement of the US in UNESCO under President George W. Bush (UN News 2002; Thomsen 2018). However, in 2005, the US Forest Service ceased to oversee the MAB programme. At the same time, the USBN, challenged by a lack of capacity, largely became inactive until the State Department took the lead in overseeing the USBN in around 2013, and the US MAB National Committee was re-established in 2015.

UNESCO requires all members of the WNBR to carry out a periodic review to ensure that the BRs still meet the criteria for their designation. Many US BRs had never conducted a periodic review in their $40+$ year histories. By 2017, 17 sites decided to withdraw from the WNBR, while two sites merged with other sites, either because they did not wish to participate in the periodic review or because they failed to meet BR criteria (Thomsen 2018). In response to a decision in 2011 of UNESCO's Executive Board to recognize Palestine as a Member State of the Organization, the US and Israel officially withdrew from UNESCO in January 2019. The State Department intends to stay engaged as a non-member observer state on non-politicized issues, including the protection of World Heritage sites, advocating for press freedoms and promoting scientific collaboration and education (US State Department 2017). Time will tell whether this period proves different from the previous withdrawal under President Reagan; however, the US is currently not engaged in decision-making leadership within UNESCO, and public awareness of UNESCO activities on the ground in the US is low.

Currently, the USBN consists of 28 BRs. Of these 28 sites, the core areas of 14 are managed by the $\mathrm{Na}$ tional Park Service (NPS); the remaining 14 are managed by a mix of the NPS, US Forest Service, National Ocean and Atmospheric Administration, US Department of Agriculture, Nature Conservancy, universi- ties, and other state and local entities. Some of the 28 sites have actively used their BR designation to achieve their landscape conservation goals and to coordinate stakeholder interests related to sustainable development. Meanwhile, other BRs that have additional designations (e.g. National Park, World Heritage Site) may not rely as heavily on the BR designation. Each of the sites in the USBN is unique, and they utilize their designation in diverse ways.

The NPS and the US MAB National Committee led the effort to conduct periodic reviews between 2016 to 2019. Over recent years, with the dissolution of this Committee as an advisory body to the US National Commission to UNESCO, a US Biosphere Working Group has been established that includes representatives from the active BRs in the USBN and others that work closely with those sites. In 2022, the Working Group is conducting a workshop for the USBN and has conducted several virtual meetings leading up to the workshop to support training, capacity and collaboration across the USBN. A Steering Committee was recently established that will provide leadership for the USBN and the Working Group. Through these efforts, the USBN is reinvigorating its activity and strategically planning for the future to overcome challenges and maximize opportunities.

\section{USBN challenges}

\section{Relevancy and inclusion}

UNESCO describes MAB as promoting "innovative approaches to economic development that are socially and culturally appropriate and environmentally sustainable" (UNESCO 2020). Further, BRs aim to be "sites for testing interdisciplinary approaches to understanding and managing changes and interactions between social and ecological systems, including conflict prevention and management of biodiversity" (UNESCO 2020). We would like to underscore the following key terms in these statements: "socially and culturally appropriate" and "interactions between social and ecological systems, including conflict prevention". Over the past 50 years, the US and the rest of the world have changed rapidly, both socially and environmentally (Steffen et al. 2011); they will continue this trajectory of change over the next 50 years as the US becomes more diverse (Frey 2019), and there is greater interaction between humans and the environment (Tilman \& Clark 2014).

While MAB considers the roles and needs of humans holistically in its vision and mission, there is room for improvement for diversity and inclusion in the USBN. The environmental movement in the US has been dominated by white voices and perspectives, largely excluding or not acknowledging the diverse interactions between different ethnicities and the environment (Finney 2014; Zimring 2017). Similarly, the US Biosphere Working Group along with past oversight committees included but a limited number of other perspectives, especially those of marginalized groups, despite UNESCO's reference to be socially 
and culturally appropriate. Many indigenous groups may view BRs as being similar to other protected areas that have a long history of displacing indigenous people and limiting their use of the land (Spence 1996; Jacoby 2014). Indigenous communities are impacted by BRs at the local level in diverse ways. For example, indigenous populations from a BR in Mexico experienced negative impacts due to BR regulations, which limited their hunting and gathering, and created perceptions of their being illegitimate resource users, while indigenous communities in a Bolivian BR perceived a lack of enforcement of logging regulations by outside settlers as a threat to their local livelihoods (Ruiz-Mallén et al. 2015, p. 102). Over the past year, the systemic racism that exists throughout US society has been brought to the forefront of our cultural public discourse (Medina 2020; Worland 2020). It is a critical element for the USBN to consider as it enters its next fifty years, in order to ensure that all stakeholders are integrated and engaged.

Gender is another element for MAB to consider in the context of a diverse and changing society. While $\mathrm{MAB}$ aims to be inclusive of all humans, the use of Man in the title is problematic, even if 50 years ago it was intended to denote mankind. In 2021, Man is not an acceptable word to indicate all people. Concerns have been raised about the programme's name and calls have been made to make it more inclusive, including at public fora such as the $3^{\text {rd }}$ World Congress of Biosphere Reserves, Madrid, 2008 (Gaines, personal communications); yet, concerns exist that if the name is changed, the historical foundation of the MAB programme and its identity may be lost. Over the past fifty years, there have been major strides in the US and elsewhere to empower gender diversity and LGBTQ rights (CNN 2020). Despite the MAB programme being nominally inclusive of gender diversity, the name itself may deter or exclude many members of society - at the least making the programme appear archaic and exclusive. There are other recent examples of major sports teams and businesses changing their names and brands to be more socially relevant and appropriate (Taylor 2020). For the US context, where MAB is making strides to reinvigorate itself and be relevant to a public that is largely unfamiliar with the programme, any new name should be a particularly important signifier for the inclusivity of the programme.

Lastly, as MAB celebrates its fifty years as an established programme, there is a need to consider how age factors into the next generation of the USBN. Many of the foundational leaders of the historic US MAB programme and individual BRs are no longer actively involved. While these leaders provide institutional knowledge, there is a need to create a bridge and engage with young professionals and youth to ensure relevancy and long-term sustainability of the programme (Reed 2016). There has been great momentum for youth involvement in the climate change crisis and other environmental movements around the world
(Neuman \& Chappell 2019; Sengupta 2019). However, due to minimal recognition of MAB among US citizens and a lack of funding to formalize a youth network, engaging young professionals has proven to be a challenge for USBN leaders. The MAB Programme established a Youth Forum in 2017 in Italy, and a subsequent Forum in 2019 in China to which the USBN sent a number of representatives. Additionally, the National Park Service, universities and non-profit organizations have created innovative educational opportunities across the USBN to engage young people aged 18-35 to support the UN's 17 sustainable development goals and MAB's core objectives. However, without a strong identity, MAB could eventually be phased out in the US as other large landscape and transboundary initiatives continue to emerge and establish themselves alongside our well-known national parks.

\section{Limited capacity of USBN}

When the US MAB Programme was established in 1974, it included several protected areas that were federally managed and did not require significant changes in operations and management (Franklin 1977). However, a UNESCO MAB Task Force also emphasized that "The planning and establishment of biosphere reserves will require expert staff and, in some instances, considerable financial resources for buildings, communication and other facilities" (UNESCO 1974, p. 36). Although the planning, establishment and periodic review of BRs require considerable financial resources and time, the day-to-day operations of most USBN sites are largely grassrootsdriven, staffed by volunteers or partner organizations, and lack dedicated or consistent funding. This discrepancy between management expectations and the local reality creates considerable challenges in establishing and maintaining active and recognized BRs in the US.

Considering the political, social and financial context that the USBN faces at the federal level, numerous USBN sites have turned to local grassroots efforts, volunteer staff and locally sourced funds to remain active. For example, Mammoth Cave BR and Cascade Head BR have agreements with local and regional partners to increase the BRs' and their partners' capacities. This model of operation and governance structure create considerable obstacles in ensuring the long-term sustainability of the USBN, since participation and stakeholder engagement fluctuate because of inconsistent funding and the availability of non-paid volunteers.

\section{Zoning and reserves}

Effective zoning of areas where there are conflicting land uses, as in buffer areas, is recognized as critical to protect biodiversity and to ensure the preservation of a protected area (Rotich 2012; Gao et al. 2019). Although it has been nearly a century since the US Supreme Court affirmed that zoning was a valid use of governmental powers (Jacobs 1998), it is another regulatory power viewed sceptically by some sectors of the 
general public in the US, as a governmental overreach on private property rights (Thomsen 2018). The lack of zoning or regional planning in private and public land areas can lead to increased habitat fragmentation, environmental contamination of sensitive habitats, and a decrease in human health (Hansen et al. 2005). Thus, effective zoning of private lands for biodiversity conservation is difficult to implement in many regions of the country, especially rural settings (Sargent et al. 1991), which has consequences on USBN sites' ability to promote sustainable development initiatives.

In the process of conducting periodic reviews of the 47 US BRs between 2016 and 2019, a process led by the National Park Service, many discussions took place regarding the functional reality and the zonation model of BRs in the context of sensitivity to private property rights in the US along with distrust of international interference. In many cases, sites fulfilled the functions of BRs without meeting the requirement of mapped concentric core, buffer and transition zones, representing increasingly more developed use. For example, in the case of the Apalachicola BR, protected land that is federally designated (through the US Forest Service) comprises the core area but is situated across the road from private property that has commercial forestry and development, with no buffer in between (P. Mangan, personal communication, September 4, 2020). This zonation was unacceptable to the Advisory Committee of the MAB Programme. Eventually, Apalachicola found a compromise, by establishing a buffer zone within the protected area designated by the US Forest Service.

Many US BRs did not reach this kind of compromise for meeting zonation requirements, and some of the original BRs were withdrawn because of such requirements as well as because of extended dormancy. Rather than viewing it as a setback, the US MAB National Committee viewed the voluntary withdrawal of 19 non-active sites as important progress towards an engaged functional network (Smith \& Greschko 2017). Other examples of US adaptations of the international zoning framework as well as of the MAB terminology exist. Two sites, Mammoth Cave Biosphere Region and Congaree Biosphere Region, have replaced the term Reserve with Region, to avoid restrictive or exclusionary connotations of Reserve, while maintaining their place-based identity and purpose with Region. Similarly, some US sites also adapted the MAB zoning terminology while maintaining the principles of the zones, selecting Area of Managed Use for Buffer Zone and Area of Partnership and Collaboration for Transition Zone. In its periodic review submissions to MAB, the USBN uses the standard MAB naming conventions in describing zones, while locally it uses varied terminology to adapt to local socio-political conditions.

Despite the challenges outlined in the previous sections, many units in the USBN have adopted innovative strategies to overcome challenges and maximize opportunities. The Champlain-Adirondack Biosphere
Network (CABN) offers a case study to illustrate some of these strategies in a mountainous ecosystem.

\section{Case study: how the Champlain-Adiron- dack Biosphere Network navigated chal- lenges and maximized opportunities}

\section{Case background}

Established in 1989, the Champlain-Adirondack Biosphere Network (CABN) is a mountainous transboundary USBN site encompassing 3990000 ha in north central New York state and northwestern Vermont (Bibles 1995). The CABN includes the Adirondack State Park (2.4 million ha; in New York), Camel's Hump Mountain and Mount Mansfield State Natural Areas (3704 ha; both in Vermont), and a portion of the Green Mountain National Forest (7 462 ha; also in Vermont). Since CABN was established, it has faced significant challenges related to zoning, land sovereignty, lack of engagement, and governance capacity. When CABN received the UNESCO designation in 1989, the situation became politically fraught as very few local communities and government officials were aware that the region had been nominated by the US Department of State for BR status (Houseal 2016). Once citizens and local officials learned of the designation in the early 1990s, there was significant opposition, particularly on the New York side, stemming from fears that the United Nations would implement additional zoning restrictions and land use regulations on top of the existing regulations imposed by local land use management agencies (Houseal 2016). As a result, $\mathrm{CABN}$ failed to launch. It was listed as inactive by UNESCO in 1995, and remained inactive until it was notified that it might be de-listed if a periodic review was not completed in 2016 (Houseal 2016). In 2016, CABN submitted the periodic review and convened a group of key officials from New York and Vermont, together with directors of Canada's Frontenac Arch Biosphere Network (FABN), to assess the feasibility of reinvigorating CABN's biosphere status. From 2016 to 2020, CABN formed a Steering Committee, developed a Strategic Plan, and began a phased approach to engage the local community, with a more inclusive strategy that aimed to counter the restrictive narrative that had prohibited CABN from gaining stakeholder buy-in when it received the designation.

As the CABN shifted out of dormancy, the Steering Committee aimed to establish CABN as a network of networks that promoted bioregional strategies to bridge the gap between New York and Vermont, and to support organizations in the biosphere which were actively addressing the United Nation's Sustainable Development Goals. The Committee also saw an opportunity to act as an aggregator and connector of interdisciplinary research and projects across the region to link otherwise disparate efforts. Furthermore, relaunching $\mathrm{CABN}$ presented a unique opportunity for thought leaders in the region to bring 
competing stakeholder interests to the table and to develop bioregional solutions to complex issues such as climate change. Three strategic partnerships facilitated the growth and reactivation of the $\mathrm{CABN}$ : 1) a Twinning Agreement with the FABN in Ontario, Canada; 2) bioregional collaborations with the Lake Champlain Basin Program, and 3) youth leadership mentoring to support sustainable communities.

\section{Partnering with the Frontenac Arch Biosphere Network}

In an effort to overcome their politically fraught past and to create a new image, CABN leaders turned to neighbouring FABN in Brockville, Ontario to understand best practices in stakeholder engagement, messaging, and how to use the designation to address competing stakeholder interests. In October 2019, CABN and FABN formalized their international partnership by signing a Twinning Agreement that focused on supporting UNESCO BR core objectives with a bioregional approach in the US and Canada. CABN and FABN have a strong sense of shared place, with numerous ecological, cultural, social and economic connections with each other. In particular, they are linked by their common position on the geological formation known as the Frontenac Axis, and on the Great Lakes and Saint Lawrence River Watershed.

In order to dispel negative connotations associated with the word reserve and to communicate a more inclusive collaboration of partnerships, the Frontenac Arch Biosphere Reserve changed its name to biosphere network. After consulting with FABN, UNESCO and their Steering Committee, CABN followed suit in 2019 and officially changed its name to the Champlain-Adirondack Biosphere Network, to create a more inclusive message and to more accurately reflect the mission of CABN.

Engaging with indigenous populations and diverse partners for bioregional thinking

CABN and FABN also sought increased engagement and reconciliation with indigenous peoples. The Twinning Agreement seeks to incorporate indigenous people's traditional ecological knowledge into management actions. In October 2019, FABN partnered with the Indigenous Environmental Institute at Trent University, Ontario Nature, Plenty Canada and the Walpole Island Land Trust to host a three-day event to share insights into, and strategies addressing, the interconnected crises of climate change and biodiversity loss. Over 100 leaders from Indigenous and nonIndigenous communities attended the event to support collaboration and resilience in an era of climate change.

The partnership with Lake Champlain Basin Program (LCBP) had a significant role in CABN's engagement at the bioregional scale by including Indigenous partners. LCBP works in collaboration with government agencies from Vermont, New York and Québec, non-profit organizations and local communities to support bioregional strategies for healthy ecosystems and communities of the Lake Champlain watershed. It oversees the Champlain Valley National Heritage Partnership (CVNHP), most of which is in the CABN and includes the ancestral home of the Iroquois and Algonquin peoples. The CVNHP provides an opportunity for $\mathrm{CABN}$ to promote, preserve and interpret the history of this region and to highlight the traditional ecological knowledge that shaped its landscape. LCBP and CVNHP's guidance and support have allowed CABN to establish a network of networks around the Lake Champlain Basin and to further strengthen their transboundary collaborations.

\section{Mentoring the next generation of biosphere leaders}

The size and scope of the CABN provided a unique opportunity for educators and practitioners in the region to mentor the next generation of leaders. Recognizing the growing need to engage young people in this effort, educators from several universities in the CABN launched youth leadership mentoring programmes that focus on BR studies and sustainable development. Paul Smith's College's Protected Landscapes and Community Sustainability Program launched an interdisciplinary programme that also involves CABN, Appenino Tosco Emiliano BR (Italy), Cape West Coast BR (South Africa), and Dreamcatchers Tourism South Africa. This initiative gives undergraduate students the opportunity to study sustainable tourism in BRs in Italy or South Africa, and to assess how local governments implement the United Nation's Sustainable Development Goals. The international collaboration helps to empower the next generation of WNBR leaders through hands-on experiential learning projects that can be adapted to a variety of landscapes and cultures.

In 2020, the State University of New York's School of Environmental Science and Forestry (SUNY-ESF) launched a Center for UNESCO BR Studies to educate and engage college students in local and international MAB initiatives (Carter 2020). The primary objectives of the centre are (1) to support CABN operations; (2) to organize collaborative education and research activities; (3) to analyse the operations of international UNESCO-designated BRs to determine best practices, and (4) to support the interdisciplinary study of BRs at SUNY-ESF. These innovative programmes serve as a model for youth engagement and education in BRs worldwide.

\section{Conclusions and recommendations}

The USBN has evolved over recent decades, influenced by a variety of social, political and environmental factors. While the USBN has made strides in achieving UNESCO's MAB goals over the past fifty years, it has also been faced with challenges that will 
influence USBN going into the future. Many of the challenges outlined in this article are not specific to the US and should be considered by the WNBR. The CABN case study offers an example of how a unit in the USBN adapted to these challenges; however, there are numerous other examples from USBN and WNBR. The following recommendations outline some key strategies and considerations for the USBN. Many of them are actively under discussion, and are also relevant to the WNBR.

1. Rename the MAB programme with a more genderinclusive title. Reflecting the current focus of the programme, the name could be the UNESCO Biosphere Programme.

2. Replace Biosphere, Reserve and Zone in individual site names with more regionally appropriate, locally acceptable, terms that align with land use while still maintaining the sites' functionality.

3. Develop inclusive approaches to bring under-represented groups and indigenous communities to discussions about resource management at the local level of the BR, and at the national level for strategic planning and policy development.

4. Ensure that youth and young professionals are included at the centre of decision making and that their active engagement is maintained.

5. Continue to engage with educational institutions at the heart of the USBN as an inclusive thinking and learning network.

6. Develop a community of practice across BRs through workshops and virtual meetings within countries and across WNBR regional networks.

7. Re-image USBN to reflect the relevance and necessity of BRs in addressing complex social-ecological challenges such as climate change, and encourage the use of biospheres as long-term research sites. Develop a database of key research and information related to the WNBR to synthesize social science, natural science and traditional ecological knowledge. Reinforce existing connections to research networks such as the Long-Term Ecological Research sites and Local and Indigenous Knowledge Systems.

8. Assess how USBN complements other designations such as National Park, World Heritage Site and large landscape initiatives, to better align goals and actions.

9. Create a governance structure of key representatives from individual units, federal and state agencies and other key groups to maintain institutional knowledge and support over time. Develop an interactive portal to enhance capacity, establish best practices, and inform sound governance as a nested approach for the USBN, regional MAB networks, and the WNBR.

UNESCO's MAB programme served as a catalyst for thinking beyond the traditional protected area model and emphasizing the integrated nature of land- scapes as social-ecological systems. While the WNBR still maintains a unique niche in sustainable development and conservation, there are numerous examples around the world of sustainable large-landscape conservation approaches (Keeley et al. 2019). Our society is constantly changing along with the environment; thus, it is critical for the WNBR to consider the challenges and opportunities outlined in this article if it is to remain relevant, inclusive and resilient. It is our hope that this article will generate meaningful discussion within the USBN and the international MAB community, and encourage being proactive rather than reactive to changes that transcend political and institutional boundaries. Many of the issues discussed in this article are not unique to the US: they should be considered for the WNBR as a whole.

\section{References}

Bibles, D. 1995. Biosphere Reserves in Action: Case Studies of the American Experience. Available at: https://www.fs.fed.us/rm/pubs_exp_forests/coram/ rmrs_1995_lusk_h001.pdf (accessed: 11/09/2020)

Carter, E.J. 2020. Center for UNESCO Biosphere Reserve Studies Concept Paper. State University of University of New York's School of Environmental Science and Forestry.

CNN 2020. LGBTQ Rights Milestones. CNN Editorial Research. Available at: https://www.cnn. com/2015/06/19/us/lgbt-rights-milestones-fastfacts/index.html (accessed: 03/09/2020)

Finney, C. 2014. Black faces, white spaces: Reimagining the relationship of African Americans to the great outdoors. Chapel Hill.

Franklin, J.F. 1977. The biosphere reserve program in the United States. Science 195: 262-267.

Frey, W.H. 2019. Six maps that reveal America's expanding racial diversity: A pre-2020 census look at the wide dispersal of the nation's Hispanic, Asian, and black populations. Available at: https://www.brookings.edu/research/ americas-racial-diversity-in-six-maps/ (accessed: 08/09/2020)

Gaines, S. 2020. July 31. Personal communication.

Gao, L., C. Ma, Q. Wang \& A. Zhou 2019. Sustainable use zoning of land resources considering ecological and geological problems in Pearl River Delta Economic Zone, China. Scientific Reports 9(1): 1-14.

Gilbert, V. 2014. Biosphere reserves: A new look at relevance to meet today's challenges. Protected Areas in a Changing World: Proceedings of the 2013 George Wright Society Conference on Parks, Protected Areas, and Cultural Sites: 31-34.

Hansen, A.J., R.L. Knight, J.M. Marzluff, S. Powell, P.H. Gude \& K. Jones 2005. Effects of exurban development on biodiversity: patterns, mechanisms, and research needs. Ecological Applications 15(6): 1893-1905.

Houseal, B. 2016. Champlain-Adirondack Biosphere Reserve Periodic Review. Adirondack Ecological Center, 
State University of New York School of Environmental Science and Forestry.

Ishwaran, N., A. Persic \& N.H. Tri 2008. Concept and practice: the case of UNESCO biosphere reserves. International Journal of Environment \& Sustainable Development 7: 118-131.

Jacobs, H.M. 1998. The "Wisdom," but Uncertain Future, of the Wise Use Movement. In, H.M. Jacobs (ed.), Who Owns America? Social Conflict Over Property Rights: 29-44. University of Wisconsin Press. Madison.

Jacoby, K. 2014. Crimes against nature: Squatters, poachers, thieves, and the bidden history of American conservation. Berkeley.

Keeley, A.T., P. Beier, T. Creech, K. Jones, R.H. Jongman, G. Stonecipher \& G.M. Tabor 2019. Thirty years of connectivity conservation planning: An assessment of factors influencing plan implementation. Environmental Research Letters 14(10): 103001.

Leiserowitz, A., E. Maibach, S. Rosenthal, J. Kotcher, P. Bergquist, M.T. Ballew, M. Goldberg \& A. Gustafson 2019. Climate change in the American mind: April 2019. Yale University and George Mason University: Yale Program on Climate Change Communication. New Haven.

Mangan, P. 2020. September 4. Personal communication.

Medina, J. 2020. Latinos Back Black Lives Matter Protests. They Want Change for Themselves, Too. The New York Times. Available at: https://www.nytimes. com/2020/07/03/us/politics/latinos-police-racismblack-lives-matter.html (accessed: 09/09/2020)

Neuman, S. \& B. Chappell 2019. Young People Lead Millions to Protest Global Inaction on Climate Change. National Public Radio. Available at: https:// www.npr.org/2019/09/20/762629200/mass-protests-in-australia-kick-off-global-climate-strike-aheadof-u-n-summit (accessed: 08/09/2020)

Reed, M.G. 2016. Conservation (in) action: Renewing the relevance of UNESCO biosphere reserves. Conservation Letters 9(6): 448-456.

Rotich, D. 2012. Concept of zoning management in protected areas. Journal of Environment and Earth Science 2(10): 173-183.

Ruiz-Mallén, I., E. Corbera, D. Calvo-Boyero, V. Reyes-García \& K. Brown 2015. How do biosphere reserves influence local vulnerability and adaptation? Evidence from Latin America. Global Environmental Change 33: 97-108.

Sargent, F.O., P. Lusk, J.A. Rivera, \& M. Varela 1991. Rural Environmental Planning for Sustainable Communities. Washington, D.C.

Sengupta, S. 2019. Protesting Climate Change, Young People Take to Streets in a Global Strike. The New York Times. Available at: https://www.nytimes. com/2019/09/20/climate/global-climate-strike.html (accessed: 15/09/2020)

Shafer, C.L. 2004. A geography of hope: pursuing the voluntary preservation of America's natural heritage. Landscape and Urban Planning 66: 127-171.
Shear, M.D. \& C. Davenport 2020. In visiting a charred California, Trump Confronts a Scientific Reality He Denies. The New York Times. Available at: https://www.nytimes.com/2020/09/13/us/politics/ california-fires-trump-climate-change.html (accessed: 18/09/2020)

Smith, C. \& M. Greschko 2017. UN Announces 23 New Nature Reserves While U.S. Removes 17. National Geographic. Available at: https://www-staging.nationalgeographic.com/news/2017/06/unesco-newbiosphere-reserves-us-withdraws-reserves/ (accessed: 08/09/2020)

Spence, M.D. 1996. Crown of the continent, backbone of the world: The American wilderness ideal and Blackfeet exclusion from Glacier National Park. Environmental History 1(3): 29-49.

Steffen, W., A. Persson, L. Deutsch, J. Zalasiewicz, M. Williams, K. Richardson, C. Crumley, P. Crutzen, C. Folke, L. Gordon, M. Molina, V. Ramanathan, J. Rockstrom, M. Scheffer, H. Schnellhuber \& U. Svedin 2011. The Anthropocene: From global change to planetary stewardship. Ambio 40(7): 739-761.

Taylor, K. 2020. 6 brands that revealed plans to change and reexamine names, mascots, and logos with racist roots this year. Business Insider. Available at: https://www.businessinsider.com/brands-thatannounced-plans-to-change-review-racist-mascotslogos-2020-6 (accessed: 15/09/2020)

Thomsen, J.M. 2018. An investigation of the critical events and influential factors to the evolution of the U.S. Man and the Biosphere program. Environmental Management 61: 545-562.

Tilman, D. \& M. Clark 2014. Global diets link environmental sustainability and human health. Nature 515(7528): 518-522.

UN News 2002. Senior UN official hails President Bush's announcement that US will rejoin UNESCO. Available at: https://news.un.org/en/story/2002/09/45012-senior-un-official-hails-president-bushs-announcementus-will-rejoin-unesco (accessed: 20/09/2020)

UNESCO 1974. Programme on Man and the Biosphere $(M A B)$ Task force on: criteria and guidelines for the choice and establishment of biosphere reserves. MAP report series No. 22, Paris. Available at: http:// npshistory.com/publications/mab/unesco-mab-report/22.pdf (accessed: $01 / 09 / 2020)$

UNESCO 2020. Man and the Biosphere (MAB) Programme. Available at: https://en.unesco.org/biosphere (accessed: 11/30/2020)

U.S. State Department Press Release 2017. The United States Withdraws From UNESCO. Available at: https://www.state.gov/the-united-states-withdrawsfrom-unesco (accessed: 18/09/2020)

Waxman, O. 2017. The U.S. Has Left UNESCO Before. Here's Why. Time Magazine. Available at: https:/ / time.com/4980034/unesco-trump-us-leavinghistory/ (accessed: 10/09/2020)

Worland, J. 2020. America's long overdue awakening on systemic racism. Time Magazine. Available at: 
https: / / time.com/5851855/systemic-racismamerica/ (accessed: 10/09/2020)

Zimring, C.A. 2017. Clean and white: A history of environmental racism in the United States. New York.

\section{Authors}

Jennifer M. Thomsen

is an Associate Professor in the Department of Society and Conservation at the University of Montana. Her work focuses on large landscape conservation, protected area management and sustainable tourism. She serves on the USBN Working Group.

\section{Kelly Cerialo}

is an Associate Professor in the Department of Business and Hospitality Management at Paul Smith's College. She serves on the USBN Working Group and is Co-Chair of the Champlain-Adirondack Biosphere Network.

\section{Sarah M. Gaines}

is a Coastal Research Associate in Climate Resilience, Conservation, and Sustainable Development at the Coastal Resources Center of the Graduate School of Oceanography, University of Rhode Island. Sarah serves as the Vice-Chair of the USBN Steering Committee.

\section{Jeremy S. Dertien}

is a Ph.D. candidate in Wildlife Biology at Clemson University and serves on the USBN Working Group. His current research focuses on spatiotemporal biodiversity dynamics and systematic conservation planning of the Congaree Biosphere Region. 